\title{
Endemic Species Residing to the Genus Hypericum L. in Azerbaijan
}

\author{
Aytan Fatdayeva, Asya Akbarova \\ Institute of Botany, Azerbaijan National Academy of Sciences, Baku, Azerbaijan \\ Email address: \\ email@ayten.fetdayeva.ru (A. Fatdayeva),email@asya1992.akbarova.ru (A. Akbarova) \\ To cite this article: \\ Aytan Fatdayeva, Asya Akbarova. Endemic Species Residing to the Genus Hypericum L. in Azerbaijan. Science Research. \\ Vol. 6, No. 1, 2018, pp. 1-3. doi: 10.11648/j.sr.20180601.11
}

Received: September 30, 2017; Accepted: November 20, 2017; Published: January 25, 2018

\begin{abstract}
Hypericum L. is the genus of flowering plants in the family Hypericaceae. The genus comprises almost 500 species of small shrubs and herbs, which has a worldwide distribution, with representatives in nearly every continent, being only absent from the poles, deserts and low-altitude tropical areas. Nowadays the largest diversity in the genus is found in the Eurasia and North America, but it is also abundant in high-altitude tropical areas of the Southern Hemisphere. Species of Hypericum do not grow the habitats that are extremely hot, cold or dry. Species of this genus grow on damp soils, meadows, swamps and even just in small water, at the region of lakes and the rivers (Hypericum eloides L.). Species meet in the foothill sand high lands, coming in to the Alpine belt.
\end{abstract}

Keywords: Hypericum, Azerbaijan, Species, Herbs, Meadows, Belt

\section{Introduction}

The first genetic description of Hypericum was given by Tournefort (1700). Linnaeus (1737) in his "Genera Plantarium" recognized the two genera Hypericum (5 petals, numerous stamens) and Ascyrum (4 petals, numerous stamens). For this species a worldwide taxonomic monograph was produced by N. Robson (between 1977 to 2012). Also he is recognized 36 sections within Hypericum.

This species has been associated with pharmacy and folklore for many centuries. Plant species of the genus Hypericum are well known for their use in traditional medicine due to the therapeutic efficacy of its many different species. For example H. perforatum L. have been used in traditional medicine based on the pharmacological properties of their active compounds such as hypericine and pseudohypericine, which are used as pain killers, antidepressants, anticancer treatments.

Hypericum belongs to the family Hypericaceae Juss.

The species of the genus Hypericum can be recognized by their opposite exstipulate entire or gland-fringed leaves, the presence of glandular secretions, and yellow bisexual flowers with petal sand sepals five in number and several stamens in 3 or 5 fascicles, ovary superior, with connate carpels, 3-5 1 ocular with free 3 style sand the presence of pale and sometimes reddish to black glandular secretions.

The characteristics feature for Hypericum is yellow colored petals, which are used to define borders of the genus. The presence of dark glands (in one organ or more) is synapomorphic trait with morphological importance, for these species. Flowers of Hypericum are generally nectarless. They are typical pollen-flowers visited by less-specialized insects. The gynoecium is typically syncarpous with an axile placentation. The fruit is a fleshy, or non-fleshy; dehiscent, or indehiscent; a capsule, or a berry, containing small cylindrical light brown to black seeds.

With a concept Enda (endemic) or an endemic element apparently special difficulties don't arise. This category is formed by the taxons extended only in the territory of the studied flora and which aren't over stepping her bounds. Thereby, endemic taxons make a specific part of flora and serve as her absolute difference from all other florae.

Endemic plants are special because they are found in only one location on the planet and now here else. The endemic plants of Azerbaijan are the most vulnerable component of its flora and loss of any of them means irreplaceable loss of biodiversity as a whole. There for by impacts of anthropogen factors many of precious shrubs in forests areas are 
extremely reduced.

There are two endemic species for Azerbaijan H. apricum (syn: H. karjagini) and $H$. theodorii.

H. apricum Kar et Kir.1842. Bull. Soc.Nat.Moscow 15:176. -H. karjaginii Rzazade, 1954, Report. AN. Azerb. SSR, 16:882. -H. elongatum auct. Non Ledeb: Grossh. 1932, Fl.Caucasian 3:71. -perennial herb, stems with rather few scattered amber glandular dots. Leaves are sessile, not glaucous, 1-veined or with up to 3 pairs of lateral branches from lower half, with laminar glands pale and sometimes a few black, marginal glands paleor 1-2 black; lamina smaller, narrow, apex obtuse to rounded. Inflorescence narrowly cylindrical, with lateral cymules 1-3-flowered, without flowering branches bellow bracts and bracteoles narrowly triangular-ovate to triangular-lanceolate, without black glands. Sepals free or united, imbricate or elliptic (or rarely ovate-elliptic) to oblong sub acute to rounded; veins 3, with regular sessile globose black glands or eglandular. Petals rather pale yellow, shortly, black-glandula ciliate. Stamens filaments not red-tinged, filaments yellow. Ovary ovoid, shortly acuminate; styles 3. Capsule ovoid-acuminate to ovoid. Seeds long dark brown. Flowering period from may till July. It grows in dry slopes and limy rocks. Found in Kuba.

H. theodorii Woronov. 1906, Flora Caucasian. 3, 9:43. perennial herb, stems numeros thin branched, absend-mindly red glandular. Leaves sessile, elliptics, 5-11mm. Inflorescence corymbose. Sepal sequal, free, ovoid with black ciliate-glands one dge, $3 \mathrm{~mm}$. Petals yellow, are longer than sepals, on edge

ciliate-glandular. Stamens are numeros. Ovary ovoid with 3 styles. Capsule brown, ovoid to ovoid-lancelote, $11 \mathrm{~mm}$. Seedss lightly curved, and longitudinally striped, $2 \mathrm{~mm}$. Flowering period from July till August. It grows in clay slopes. Found in Kobustan.

\section{Materials and Methods}

Plant materials were collected in 2015-2016 in Qobustan and Quba districts of Azerbaijan. Also the herbarium specimens stored in the Herbarium fond of the Institute of Botany ANAS were used in this study. Classic comparative morphological methods were used for identification of species.

\section{Result}

Taxonomy of this genus, have not been studied for many years in Azerbaijan. Only few species of genus have been studied by R. Rzazade (1955). Our aim is to study the endemic species of the Hypericum growing in Azerbaijan.

\section{Conclusion}

Another critical problem is the continuous practice of illegal grazing for fire wood in the forests which are damaging the biodiversity and are resulting in economic and social losses. Due to the poor management in many regions, and especially villages located in proximity to the forests, acts of illegal logging existand pose a significant threat to the forests. The same threat comes from the unsustainable tourism and recreation practices. At the same time the forests of Azerbaijan feel the impact of the global climate change with an increase of forest fires during the summer. For this reason the territory of endemic species has to be protected. 17 species of Hypericum genus was registered in Azerbaijan (Конс. Фл. Кавказа 2012). These are H. androsaemum L., $H$. apiculatum N. Robson., H. apricum Kar et Kir., H. davisii N. Robson., $H$. elongatum Ledeb., $H$. formosissimum Takht., $H$. hirsutum L., H. linaroides Bosse., $H$. lydium Boiss., $H$. nummularoides Trautv., H. perforatum L., H. pseudolaeve $\mathrm{N}$. Robson., H. scabrum L., H. tetrapterum Fries., H. theodorii Woronov., H. venustum Fenzl., H. xylosteifolium (Spach) N. Robson. Only two of them are endemic species for Azerbaijan- H. apricum (syn: H. karjagini) and H. theodorii. These endemic species belongs to the sections Hirtella Stef. (H. apricum Kar et Kir.) and Taeniocarpium Jaub et Spach. (H. theodorii Woronov.) Table 1.

Table 1. Endemic species of the genus Hypericum L. in sections

\begin{tabular}{lll}
\hline Sections & Characteristic features of sections & Species \\
\hline Hirtella Stef. & $\begin{array}{l}\text { Perennial herbs, with branched } \\
\text { emergences, rarely glandular, with } \\
\text { stems decumbent at the base from } \\
\text { taproot. }\end{array}$ & $\begin{array}{l}\text { H. apricum Kar } \\
\text { etKir }(\mathrm{H} . \\
\text { karjaginii } \\
\text { Rzazade. }\end{array}$ \\
$\begin{array}{l}\text { Taeniocarpium } \\
\text { Jaub et Spach. }\end{array}$ & $\begin{array}{l}\text { pubescent with stems erect to } \\
\text { rooting and branching from taproot. }\end{array}$ & $\begin{array}{l}\text { H. theodorii } \\
\text { Woronov. }\end{array}$ \\
\hline
\end{tabular}

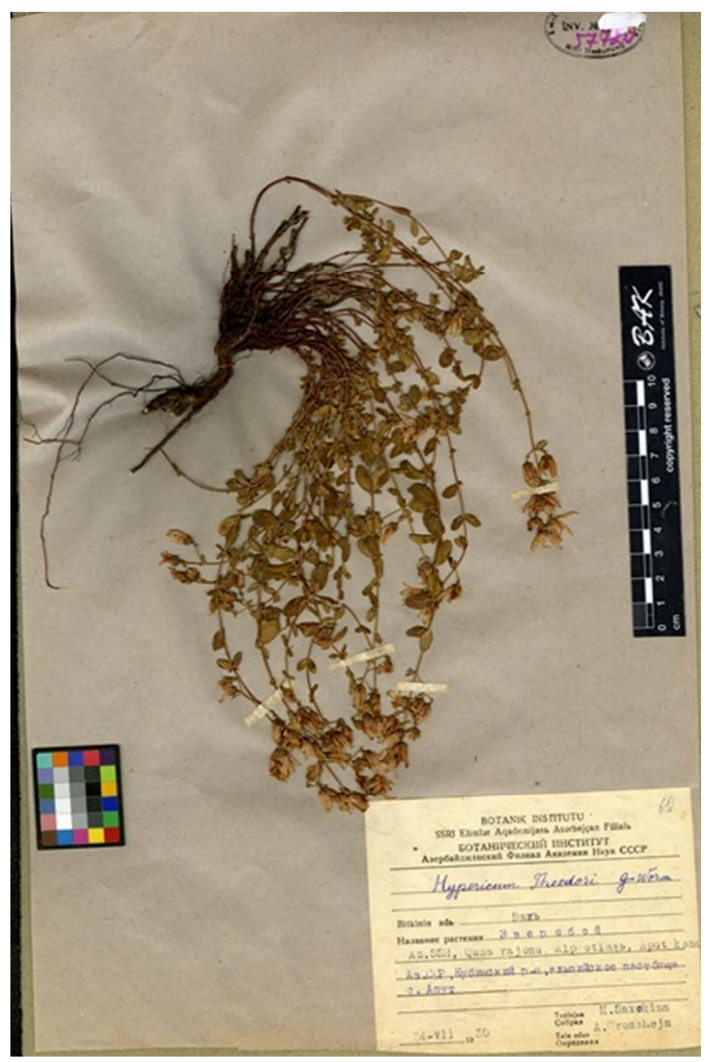

Figure 1. H. theodorii Woronov. 


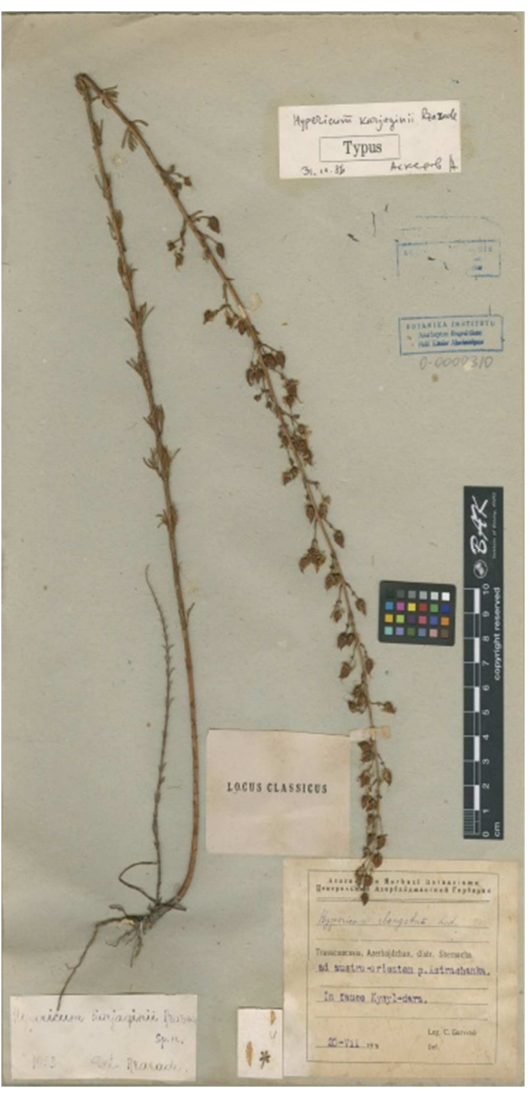

Figure 2. H. apricum Kar et Kir.(H. karjaginii Rzazade).

\section{References}

[1] "Species plantarium", K. Linney, Vol. II, London, 1753, P.783-784.

[2] "Flora orientalis" Ed. by Boissier E. Vol. 1. Genevae, 1867, P.1017-1025.

[3] R. Rzazade (1955). "Flora of Azerbaijan" Baku, P.248-259.

[4] P. H. Davis (1967). "Flora of Turkey" Edinburg, P.355-401.

[5] А. А. Гроссгеим (1936). "Flora of Azerbaijan", Baku, P.500504.

[6] А. А. Гроссгеим (1962).“Caucasian flora”, Vol 4, Москва. C.163-177.

[7] Goroshkova S. (1949). Genus Hypericum L. "Flora of SSR", Leningrad, ANSSR, Vol 15, P.203-258.

[8] A. R. Claphan, T. G. Tutin, D. M. Moore "Flora of British isles", Cambridge, 1958, P.256-262.

[9] Сенников А. Н. "Flora of Eastern Europe" СПб., 1996. Vol .9. P.173-177.

[10] Abstract of the Caucasian flora, Vol. 3(2), Москва, 2012. P.308-31. 